\title{
KEWENANGAN PIMPINAN PARTAI POLITIK DALAM PENGUSULAN PEMBERHENTIAN ANGGOTA DPR TERKAIT TINDAK PIDANA KORUPSI ${ }^{1}$
}

\author{
Oleh : \\ Bambang Budiyanto
}

\begin{abstract}
Abstrack
Political parties have a strategic role in a democratic country. Indonesian 1945 Constitution regulates the status of political parties in the state life in Indonesia. Political parties are the only organization that can become participants in the elections and nominate candidates to fill political positions. One of the authorities of political parties is to nominate candidates of legislators both at the central and regional levels. In addition to nominating candidates for members of Parliament, political parties also have the authority to dismiss members of political parties in the Parliament. Departing from this issue, this study discusses two main problems related to the authority of political parties against the dismissal of the members of the House of Representatives in Indonesia as well as on construction of the arrangements for the provision of dismissal of members of parliament tied to corruption. This research was conducted with the use of normative legal research conducted through an analysis of the norms of the legislation.The study results show that political parties have a very important role in democracy and runningthe country. In addition to the authority ofnominating candidates to fill political positions in the executive and legislative, political parties are also given the authority to replacement and dismissal of members of the House of Representatives. Related to the dismissal of members of the party sitting in Parliament, the political parties should set very important conditions such as the problem of corruption. This serves as a precautionary measure and efforts to realize corruption-free state officials, because corruption has a very serious impact on the life of the nation. Thus the judicial review provided for in Article 16 of Law No. 2 of 2011 concerning the Amendment Act No. 2 of 2008 on Political Parties needs to be done, and then revised. This is to fill the void of legal norms tied to provisions of the dismissal of members of political parties in the House of Representatives due to corruption.
\end{abstract}

Keywords: Authority, Political Party, House of Representatives, Corruption.

\footnotetext{
Abstrak

Partai politik mempunyai peran strategis dalam negara demokrasi. UUD NRI 1945 telah mengatur kedudukan partai politik dalam kehidupan bernegara di Indonesia. Partai politik adalah satu-satunya organisasi yang dapat menjadi peserta pemilu dan mengajukan calon untuk mengisi jabatan-jabatan politik.

1 Artikel ini merupakan karya ilmiah mahasiswa pada Program Studi Magister (S2) Ilmu Hukum Program Pascasarjana Universitas Udayana serta mengucapkan terimakasih kepada Prof. Dr. Ibrahim R., SH.,MH dan Prof. Dr. I Made Subawa, SH.,MS selaku Pembimbing tesis

2 Mahasiswa magister ilmu hukum Universitas Udayana, email: b.budiyanto35@yahoo.com
} 
Salah satu kewenangan partai politik adalah mengajukan calon anggota DPR baik di pusat maupun di daerah. Selain mengajukan calon anggota DPR, partai politik berwenang memberhentikan anggota partai politik yang duduk di DPR. Bertolak dari hal tersebut, penelitian ini membahas dua pokok permasalahan yaitu yang berkaitan kewenangan pimpinan partai politik dalam mengusulkan pemberhentian anggota DPR terkait tindak pidana korupsi serta tentang konstruksi pengaturan terhadap ketentuan pemberhentian anggota DPR terkait tindak pidana korupsi. Penelitian ini dilaksanakan dengan menggunakan penelitian hukum normatif yang dilakukan melalui analisis terhadap norma dalam peraturan perundang-undangan. Berdasarkan hasil penelitian ini bahwa partai politik mempunyai peran sangat penting dalam demokrasi dan penyelenggaraan negara. Selain diberikan kewenangan untuk mengajukan calon-calon untuk mengisi jabatan-jabatan politik di eksekutif dan legislatif, partai politik juga diberikan kewenangan untuk melakukan pergantian dan pemberhentian anggota DPR. Terkait dengan pemberhentian anggota partai yang duduk di DPR seharusnya mengatur ketentuan yang sangat penting seperti masalah korupsi. Hal ini sebagai langkah pencegahan dan dalam upaya mewujudkan penyelenggara negara yang bebas KKN, sebab korupsi mempunyai dampak sangat serius dalam kehidupan berbangsa dan bernegara. Dengan demikian judicial review dalam ketentuan Pasal 16 UU No. 2 Tahun 2011 tentang Perubahan Atas Undang-Undang Nomor 2 Tahun 2008 tentang Partai Politik perlu dilakukan, yang selanjutnya dilakukan direvisi. Hal ini untuk mengisi kekosongan norma hukum terkait ketentuan pemberhentian anggota partai politik di DPR yang disebabkan tindak pidana korupsi.

\section{Kata Kunci: Kewenangan, Partai Politik, Dewan Perwakilan Rakyat, Tindak Pidana Korupsi.}

\section{PENDAHULUAN}

Pasca reformasi keberadaan partai politik sangat mewarnai kehidupan berbangsa dan bernegara. Dalam berbagai perhelatan politik, partai politik menjalankan peran pentingyangmenentukan. Amandemen UUD 1945, memberikan ruang yang cukup besar terhadap partai politik dalam penyelenggaraan pemerintahan. Partai politik mempunyai kedudukan yang sangat penting dalam sistem ketatanegaraan di Indonesia, sebab partai politik diberikan wewenang untuk mengajukan kader-kader terbaiknya untuk dicalonkan mengisi jabatan-jabatan politik dari pusat sampai daerah. Kewenangan yang cukup besar dan menentukan yang diberikan oleh UUD NRI 1945 inilah yang menempatkan partai politik mempunyai posisi sangat strategis.

Salah satu fungsi penting partai politik adalah rekrutmen politik yaitu proses untuk pengisian jabatanjabatan politik. Terkait dengan fungsi rekrutmen politik ini telah diatur dalam UU No. 2 Tahun 2011 tentang Perubahan Atas UU No. 2 Tahun 2008 tentang Partai Politik, Pasal 29 ayat 
(1) menentukan bahwa:Partai politik melakukan rekrutmen terhadap warga negara Indonesia untuk menjadi:

a. anggota Partai Politik;

b. bakal calon anggota Dewan Perwakilan Rakyat dan Dewan Perwakilan Rakyat Daerah;

c. bakal calon kepala daerah dan wakil kepala daerah; dan

d. bakal calon Presiden dan Wakil Presiden.

Dengan memperhatikan

kedudukan partai politik yang telah diatur baik di dalam UUD NRI 1945 dan UU No. 2 Tahun 2011, jelas bahwa partai politik merupakan pilar demokrasi yang berperan penting bagi kelangsungan suatu negara. Dapat pula dikatakan bahwa partai politik merupakan penentu bagi kemajuan atau kemunduran suatu bangsa, sebab para pemangku kekuasaan dari pusat sampai daerah berasal dari partai politik. Partai politik di negara kita adalah pemasok utama legislator atau wakilrakyat. ${ }^{3} \mathrm{Hal}$ ini sebagaimana telah diatur dalam konstitusi kita, bahwa untuk menjadi wakil rakyat melalui pemilihan umum harusmenjadi anggota partai politik dan melalui pencalonan yang dilakukan oleh partaipolitik.

Selain diberikan kewenangan untuk mengajukan calon-calon untuk mengisi jabatan-jabatan politik, partai politik juga diberikan kewenangan

3 Ichlasul Amal \& Samsurizal Panggabean, 2012, Reformasi Sistem Multi Partai Dan Peningkatan Peran DPR Dalam Proses Legislatif, dalam Ichlasul Amal, Dkk, Editor, Teori-Teori Mutakhir Partai Politik, Tiara Wacana, Yogyakarta, hlm. 177. untuk melakukan pergantian dan pemberhentian seseorang dari keanggotaannya di partai politik sekaligus di DPR yang dikenal dengan istilah "recall"

Terkait dengan kewenangan tersebut di atas UU No. 2 Tahun 2011 tentang Perubahan Atas UU No. 2 Tahun 2008 tentang Partai Politik, Pasal 16 mengatur:

(1) Anggota

Partai

Politik diberhentikan keanggotaannyadari Partai Politik apabila:

a. meninggal dunia;

b. mengundurkan diri secara tertulis;

c. menjadi anggota Partai Politik lain; atau

d. melanggar AD dan ART.

(2) Tata cara pemberhentian keanggotaan Partai Politik sebagaimana dimaksud pada ayat (1) diatur di dalam AD dan ART.

(3) Dalam hal anggota Partai Politik yang diberhentikan adalah anggota lembaga perwakilan rakyat, pemberhentian dari keanggotaan Partai Politik diikuti dengan pemberhentian dari keanggotaan di lembaga perwakilan rakyat sesuai dengan peraturan perundang-undangan.

Perbuatan tindak pidana korupsi merupakan pelanggaran terhadap hak-hak sosial dan hakhak ekonomi masyarakat, sehingga 
tindak pidana korupsi tidak dapat lagi digolongkan sebagai kejahatan biasa, melainkan telah menjadi kejahatan luar biasa. Sehingga dalam upaya pemberantasannya tidak lagi dapat dilakukan secara biasa, tetapi dituntut dengan cara-cara luar biasa pula. Banyaknya penyelenggara negara khususnya anggota DPR yang terlibat kasus korupsi, mengindikasikan gagalnya pendidikan politik dan sistem rekrutmen yang dilakukan oleh partai politik. Sebagai penyelenggara negara, anggota DPR yang melakukan tindak pidana korupsi merupakan orang-orang yang dicalonkan oleh partai politik.

Menurut Reydonnyzar Moenek, salah satu alasan maraknya anggota DPR/DPRD dan Kepala Daerah tersangkut kasus hukum terutama tindak pidana korupsi adalah pelaksanaan pemilukada langsung dan model rekrutmen terbuka. ${ }^{4}$ Dimana siapa saja dapat menjadi anggota DPR/ DPRD dan Kepala Daerah, ditambah lagi tingginya biaya pencalonan, sehingga mereka akan mencari cara untuk mengembalikan modalnya.

Kewenangan

Pimpinan

partai politik dalam mengusulkan pemberhentian anggota DPR terkait tindak pidana korupsi dalam ketentuan Pasal 16 ayat (1) UU No. 2 Tahun 2011, tidak mengatur syarat pemberhentian anggota DPR karena faktor tindak

4 Ruslan, Ismail Mage, 2013, Berpolitik Dengan Biaya Murah (Solusi Mencegah Politisi Korupsi), Thafa Media, Yogyakarta, hlm. 250-251. pidana korupsi, maka ketentuan dalam Pasal 16 ayat (1) terjadi kekosongan norma hukum. sehingga penulis tertarik untuk menjadikannya suatu penelitian dengan judul "Kewenangan Pimpinan Partai Politik Dalam Mengusulkan Pemberhentian Anggota DPR Terkait Tindak Pidana Korupsi."

Adapun permasalahan yang dapat ditarik dari latar belakang diatas adalah sebagai berikut :

1. Bagaimanakah kewenangan pimpinan partai politik dalam mengusulkan pemberhentian anggota DPR terkait tindak pidana korupsi?

2. Bagaimanakah konstruksi pengaturan terhadap pemberhentian anggota DPR oleh pimpinan partai politik terkait tindak pidana korupsi?

Orisinalitas dalam penelitian ini pertama dari artikel jurnal oleh Jimly Asshiddiqie berjudul Partai Politik dan Pemilihan Umum sebagai instrumen demokrasi dari jurnal konstitusi volume 3 nomor 4 tahun 2006 menyimpulkan hubungan hukum, bukan hanya dengan partai politik yangmerekrut dan mencalonkan nya dalam pemilihan umum, tetapipilihan rakyat pemilih yang kemudian dikukuhkan dengan pengangkatan dan pengambilan sumpah sebagai anggota DPR, telah melahirkan hubungan hukum baru di samping yang telahada antara partai politik yang mencalonkan dan calon terpilih. Kedua artikel jurnal oleh Imam Yudhi Prasetya berjudul 
Pergeseran Peran Ideologi Dalam Partai Politik dari jurnal ilmu politik dan ilmu pemerintahan volume 1 nomor 1 tahun 2011 menyimpulkan ideologi yang seharus dijadikan landasan partai politik beserta kadernya dalam melakukan kerja-kerja politik yang menyangkut banyak hal tetapi ideologi dijadikan konten pencitraan yang acapkali manipulatif. Ideologi kemudian hanya menjadi aksesoris dari partai politik, ideologi dikalahkan oleh kepentingan jangka pendek para elit partai politik dalam mengejar kepentingan pribadi. Fenomena menyulitkan untuk mendapatkan calon yang tepat, bukan karena keterbatasan infomasi tetapi karena banyaknya informasi yang ditawarkan tokoh dengan pencitraannya melalui media yang ada, diharapkan kita lebih hatihati dalam menentukan pilihan (dalam pemilu).

Dari penelitian-penelitian terdahulu yang telah dipaparkan diatas perbedaannya terhadap penelitian ini adalah pengkajian dari hasil penelitian ini menjadi suatu hal baru ditinjau dari kewenangan pimpinan partai politik terhadap anggota DPR yang terlibat tindak pidana korupsi.

Tujuan dari penelitian ini adalah sebagai berikut: menganalisa dan mengetahui kewenangan yang diberikan oleh undang-undang terkait pemberhentian keanggotaan seseorang di partai politik dan di DPR yang melakukan tindak pidana korupsi; selain itu untuk mengkaji kewenangan partai politik terhadap pemberhentian anggota DPR yang melakukan tindak pidana korupsi di Indonesia; dan mengkaji tentang konstruksi pengaturan terhadap pemberhentian anggota DPR terkait tindak pidana korupsi di Indonesia.

\section{METODE PENELITIAN}

Metode penelitian ini adalah penelitian hukum normatif. Dipilihnya jenis penelitian hukum normatif karena penelitian ini menguraikan permasalah-permasalahan yang ada, untuk selanjutnya dibahas dengan kajian berdasarkan teori-teori hukum kemudian dikaitkan dengan peraturan perundang-undangan yang berlaku dalam praktek hukum. ${ }^{5}$ Penelitian hukum normatif tersebut mencakup beberapa hal yaitu penelitian terhadap asas-asas hukum, penelitian terhadap sistematika hukum, penelitian terhadap taraf sinkronisasi hukum dalam arti vertikal maupun horizontal, perbandingan hukum dan sejarah hukum. ${ }^{6}$ Pendekatan yang dipergunakan dalam penelitian ini adalah Pendekatan perundangundangan (statute approach); Suatu penelitian normatif tentu harus menggunakan pendekatan perundangundangan, karena yang akan diteliti adalah berbagai aturan hukum yang menjadi fokus sekaligus tema sentral

5 Soerjono Soekanto,2006, Penelitian Hukum Normatif (Suatu Tinjauan Singkat), PT. Grafindo Persada, Jakarta, hlm.13.

6 Zainuddin, 2011, Metode Penelitian Hukum, Sinar Grafika, Jakarta, hlm. 25-30. 
suatu penelitian. ${ }^{7}$ Pendekatan undangundang (statute approach) dilakukan dengan menelaah semua undangundang dan regulasi yang bersangkut paut dengan isu hukum yang sedang ditangani. Hasil dari telaah tersebut merupakan suatu argumen untuk memecahkan isu yang dihadapi. ${ }^{8}$ Dan Pendekatan konseptual (conceptual approach), bahwa pendekatan konseptual biasanya digunakan untuk menguraikan dan menganalisis permasalahan penelitian yang beranjak dari adanya norma kosong. ${ }^{9}$ Pendekatan konseptual beranjak dari pandangan-pandangan dan doktrindoktrin yang berkembang di dalam ilmu hukum. Dengan mempelajari pandangan-pandangan dan doktrindoktrin di dalam ilmu hukum, peneliti akan menemukan ide-ide yang melahirkan pengertian-pengertian hukum, konsep-konsep hukum, dan asas-asas hukum yang relevan dengan isu yang dihadapi. ${ }^{10}$

7 Johnny Ibrahim, 2013, Teori \& Metodologi Penelitian Hukum Normatif (Edisi Revisi), Bayumedia Publising, Malang, hlm. 303.

8 Peter Mahmud Marzuki, 2010, Penelitian Hukum, Kencana Prenada MediaGroup, Jakarta, hlm. 93.

9 I Made Pasek Diantha, 2016, Metodologi Penelitian Hukum Normatif (Dalam Justifikasi Teori Hukum), Prenada Media Group, Jakarta, hlm. 159.

10 Peter Mahmud Marzuki, 2010, Penelitian Hukum, Kencana Prenada MediaGroup, Jakarta, hlm.95.
III. HASIL DAN PEMBAHASAN

3.1. Kewenangan Pimpinan Partai Politik dalam Mengusulkan pemberhentian anggota DPR terkait tindak pidana korupsi

Dalam demokrasi perwakilan, kekuasaan tertinggi (kedaulatan) beradadi tangan rakyat, tetapi dalam pelaksanaannya dijalankan oleh wakilwakil rakyat yang dipilih melalui pemilu. Pada umumnya negara-negara yang menyelenggarakan demokrasi perwakilan dengan jalan yang berbedabeda, sesuai dengan kebutuhan dan kondisi suatu negara. Perbedaan dimaksud antara lain menunjuk pada:

1. cara penyusunan lembaga perwakilan;

2. cara dari wakil-wakil rakyat menduduki lembaga perwakilan;

3. cara pengambilan keputusan dalam lembaga perwakilan;

4. tugas dan wewenang lembaga perwakilan, yang erat kaitannya dengan rincian materi muatan yang terkandung dalamkonstitusi masing-masing negara. ${ }^{11}$

Demokrasi

perwakilan dilaksanakan dalam situasi negara dengan jumlah penduduk yang besar, dan wilayah yang sangat luas. Dengan kondisi demikian, demokrasi dilakukan melalui perwakilan, dengan cara melakukan pemilu. Tujuan

11 Eddy Purnama, 2007, Negara Kedaulatan Rakyat,Analisis TerhadapSistemPemerintahan Indonesia dan Perbandingannya Dengan Negara-negara Lain, Nusamedia, Bandung, hlm. 212. 
pelaksanaan pemilu adalah terpilihnya wakil rakyat dan terselenggaranya pemerintahan yang benar-benar sesuai dengan pilihan rakyat. Pemilu yang tidak mampu mencapai tujuan itu hanya akan bersifat formalitas sebagai pemberian legitimasi bagi pemegang kekuasaan negara, pemilu demikian adalah pemilu yang kehilangan ruh demokrasi.

Menurut Jimly, tujuan penyelenggaraan pemilihan umum itu ada 4 (empat), yaitu untuk:

a. untuk memungkinkan terjadinya peralihan kepemimpinan pemerintahan secara tertib dan damai;

b. untuk memungkinkan terjadinya pergantian pejabat yang akan mewakili kepentingan rakyat di lembaga perwakilan;

c. untuk melaksanakan prinsip kedaulatan rakyat; dan

d. untuk melaksanakan prinsip hakhak asasi warga negara. ${ }^{12}$

Lembaga perwakilan rakyat atau parlemen disebut dengan berbagai macam istilah sesuai dengan bahasa yang dipakai di setiap negara. Bentuk, susunan, kedudukan, dan kewenangannya pun beraneka ragam sesuai dengan perkembangan kebutuhan setiap negara. Namun secara umum, lembaga perwakilan rakyat itu pada mulanya dipandang sebagai representasi mutlak warga negara

12 Jimly Assiddiqie, 2006, Partai Politik Dan Pemilihan Umum Sebagai Instrumen Demokrasi, Jurnal Konstitusi, Vol. 4, Nomor 3, Desember, hlm. 13. dalam rangka ikut serta menentukan jalannya pemerintahan. Apa yang diputuskan oleh parlemen, itulah yang dianggap sebagai keputusan rakyat yang berdaulat. ${ }^{13}$

Wakil rakyat terpilih yang ditetapkan berdasarkan perolehan suaraterbanyak memiliki legitimasi politik yang kuat. Hal mana legitimasi seperti itu tidak didapatkan dalam sistem dengan mekanisme penentuan calon terpilih berdasarkan nomor urut. ${ }^{14}$ Hasil pemilu yang diselenggarakan dalam suasana keterbukaan dengan kebebasan berpendapat dan kebebasan berserikat, dianggap dengan cukup akurat mencerminkan partisipasi serta aspirasi masyarakat. ${ }^{15}$

Dalam hal pemilihan umum untuk memilih wakil rakyat di lembaga DPR, Pasal 19 Ayat (1) UUD NRI 1945, menentukan bahwa: "Anggota Dewan Perwakilan Rakyat dipilih melalui Pemilihan Umum”. Ketentuan tersebut mewujudkan bahwa rakyatlah pemegang kedaulatan tertinggi. Hal ini merupakan wujud pelaksanaan dari pembukaan UUD NRI Tahun 1945, dan semakin mengokohkan legitimasi DPR sebagai wakil rakyat.

Dewan Perwakilan Rakyat mempunyai fungsi, kewenangan, tugas dan hak-hak sebagai anggota

13 Jimly Asshiddiqie,2008, Pokok-Pokok Hukum Tata Negara Indonesia, Bhuana Ilmu Populer, Jakarta, hlm.153.

14 Khairul Fahmi, 2011, Pemilihan Umum \& Kedaulatan Rakyat, Rajagrafindo Persada, Jakarta, hlm. 268.

15 Cholisin \& Nasiwan, 2012, Dasar-Dasar Ilmu Politik, Ombak, Yogyakarta, hlm. 134. 
yang telah diatur baik dalam UUD NRI 1945 maupun dalam undang-undang. Abcarian dan Masnnat mengatakan bahwa secara tradisional, fungsi utama lembaga-lembaga legislatif adalah menetapkankebijaksanaanumum yang mengikat seluruh anggota masyarakat secara autoritatif. ${ }^{16}$

Dalam konteks Indonesia menurut Jimly, peran dan fungsi Dewan Perwakilan Rakyat mencakup tiga komponen utama yaitu fungsi legislasi, fungsi anggaran dan fungsi pengawasan. ${ }^{17}$ Hal inisebagaimana ketentuan dalam Pasal 20A ayat (1) UUD NRI 1945, bahwa:"Dewan Perwakilan Rakyat memiliki fungsi legislasi, fungsi anggaran,dan fungsi pengawasan."

Dalam perjalanannya anggota DPR yang merupakan wakil rakyat banyak yang tersangkut kasus korupsi, sehingga menunjukkan lemahnya sistem kaderisasi oleh partai politik. Hal ini tentu sangat bertolak belakang dengan peran partai politik yang sangat sentral, sebab rekrutmen hampir dari semua lembaga negara melibatkan partai politik yang memiliki kursi di DPR.

Dalam hal pemberhentian anggota DPR, Pasal 22B UUD NRI 1945 telah mengatur sebagai berikut; "Anggota Dewan Perwakilan Rakyat dapat diberhentikan dari jabatannya,

16 Paimin Napitupulu, 2007, Мепијu Pemerintahan Perwakilan, Alumni, Bandung, hlm.25.

17 Jimly Assidiqqie, 2015,Pengantar Ilmu Hukum Tata Negara, RadjaGrafindo Persada, Jakarta, hlm. 300. yang syarat-syarat dan tata caranya diatur dalam undang-undang”. Ketentuan Pasal 22B UUD NRI 1945 tersebut di atas terkait pemberhentian anggota DPR dari jabatannya. Tentang syarat dan tata cara pemberhentian tersebut ditindaklanjuti dengan pengaturan lebih khusus, termasuk lembaga yang diberi kewenangan untuk melaksanakannya.

UU No. 2 Tahun 2011 tentang Perubahan Atas UU No. 2 Tahun 2008 tentang Partai Politik dan UU No. 17 tahun 2014 tentang MPR, DPR, DPD dan DPRD, yang memuat ketentuan tentang pemberhentian anggota DPR. Dari ketentuan atas kedua undang-undang tersebut di atas, maka partai politik diberikan kewenangan untuk melakukan pergantian dan pemberhentian anggota DPR.

Terkait dengan pemberhentian anggota DPR, UU No. 17 Tahun 2014 tentang MPR, DPR, DPD Dan DPRD, mengatur sebagai berikut: Pasal 239 ayat (2) huruf d dengan ketentuan: "anggota DPR dapat diberhentikan apabila diusulkan oleh partai politiknya sesuai dengan ketentuan peraturan perundang-undangan". Pasal 239 ayat (2) huruf $g$ dengan ketentuan: "anggota DPR dapat diberhentikan apabila diberhentikan sebagai anggota partai politik sesuai dengan ketentuan peraturan perundang-undangan". Pasal 240 ayat (1) "Pemberhentian anggota DPR sebagaimana dimaksud dalam Pasal 239 ayat (1) huruf a dan huruf b serta pada ayat (2) huruf c, 
huruf d, huruf g, dan huruf h diusulkan oleh pimpinan partai politik kepada pimpinan DPR dengan tembusan kepada Presiden".

Adapun ketentuan dalam Pasal 16 ayat (3) UU No. 2 Tahun 2011 tentang Perubahan Atas UU No. 2 Tahun 2008 Tentang Partai Politik, mengatur sebagai berikut:"Dalam hal anggota Partai Politik yang diberhentikan adalah anggota lembaga perwakilan rakyat, pemberhentian dari keanggotaan Partai Politik diikuti dengan pemberhentian dari keanggotaan di lembaga perwakilan rakyat sesuai dengan peraturan perundang-undangan”.

Dalam ketatanegaraan wewenang dideskripsikan sebagai kekuasaan hukum (rechtsmacht). ${ }^{18}$ Wewenang tersebut mempunyai legitimasi yang kuat darirakyat, karena pada dasarnya undang-undang dibuat oleh wakil rakyat. J.G Brouwer berpendapat pada atribusi, kewenangan diberikan kepada satu organ (institusi) pemerintahan atau lembaga negara oleh suatu badan legislatif yang independen. Kewenangan ini adalah asli, yang tidak diambil dari kewenangan sebelumnya. Badan legislatif menciptakan kewenangan yang mandiri dan bukan perluasan kewenangan sebelumnya dan memberikan kepada organ yang berkompeten. ${ }^{19}$

18 Mustafa Lutfi, 2010, Hukum Sengketa Pemilukada Di Indonesia, UII Press, Yogyakarta, hlm.11.

19 Ibid, hlm.15.
Dari ketentuan Pasal 16 UU No. 2 Tahun 2011 tentang Perubahan Atas UU No. 2 Tahun 2008 Tentang Partai Politik, maka berdasarkan ketentuan tersebut di atas, sumber kewenangan partai politik dalam hal pemberhentian anggota partai politik di DPR langsung dari Undang-Undang (atribusi).

Putusan MK Nomor 008/PUUIV/2006 tentang pengujian Pasal 85 ayat (1) huruf c Undang-undang Republik Indonesia Nomor 22 Tahun 2003 tentang Susunan dan Kedudukan MPR, DPR, DPD, dan DPRD dan Pasal 12 huruf $b$ Undang-undang Nomor 31 Tahun 2002 tentang Partai Politik dan Putusan MK Nomor 38/ PUU-VIII/2010 tentang Pengujian Pasal 213 ayat (2) huruf e dan huruf h Undang-Undang Nomor 27 Tahun 2009 tentang MPR, DPR, DPD dan DPRD, telah menguatkan kedudukan partai politik dalam hal kewenangan dalam pemberhentian anggota partai politik di DPR.

Kewenangan yang sangat strategis ini tentunya tidak boleh dipergunakan untuk kepentingankepentingan pribadi atau kelompok. Kewenangan ini sudah seharusnya untuk meningkatkan peran penting partai politik, khususnya yang anggotaanggotanya duduk di DPR untuk kepentingan bangsa dan negara. 


\subsection{Bagaimanakah konstruksi pengaturan terhadap pemberhentian anggota DPR oleh pimpinan partai politik terkait tindak pidana korupsi}

Pemerintahan yang demokratis pada dasarnya adalah pemerintahan yang mengedepankan kebebasan untuk membangun partisipasi warga negaranya, yang sekaligus harus diimbangi dengan ketaatan pada norma hukum yang berlaku, baik oleh pemerintah maupun oleh warga negaranya tanpa ada pengecualian (equality before the law).

Dalam UUD NRI 1945 Amandemen, kedudukan partai politik telah diatur dan mempunyai posisi sangat strategis dalam ketatanegaraan di Indonesia. Beberapa pasal yang mengatur tentang partai politik dalam UUD NRI 1945 adalah sebagai berikut:

Pasal 6A Ayat (2), dengan ketentuan bahwa:

"Pasangan calon Presiden dan Wakil Presiden diusulkan oleh partai politik atau gabungan partai politik peserta pemilihan umum sebelum pelaksanaan pemilihan umum".

Pasal 22E Ayat (3), dengan ketentuan bahwa:

"Peserta pemilihan umum untuk memilih anggota Dewan Perwakilan Rakyat dan anggota Dewan Perwakilan Rakyat Daerah adalah partai politik".

Selanjutnya terkait dengan pemilihan Gubernur, Bupati dan Walikota dalam Pasal 18 ayat (4)
UUD NRI 1945, bahwa pemilihannya dilakukan secara demokratis. Ketentuan Pasal 18 ayat (4) ini, dalam hal rekrutmen ditindaklanjuti dan diatur dalam undang-undang partai politik.

Pasal29 Ayat(1)UUNo.2 Tahun 2011, menentukan bahwa:"Partai Politik melakukan rekrutmen terhadap warganegara Indonesia untuk menjadi:

a. anggota Partai Politik;

b. bakal calon anggota Dewan Perwakilan Rakyat dan Dewan Perwakilan Rakyat Daerah;

c. bakal calon kepala daerah dan wakil kepala daerah; dan

d. bakal calon Presiden dan Wakil Presiden".

DPR dibentuk oleh rakyat lewat partai politik merupakan lembaga yang amat penting untuk demokrasi, karena mereka yang menempati kursi di lembaga tersebut adalah wakilwakil rakyat. Pekerjaan utama mereka adalah memikirkan kepentingan dan kebutuhan rakyat yang mereka wakili, mengidentifikasi masalahmasalah yang dihadapi rakyat, dan menyusun undang-undang yang menjamin terwujudnya kepentingan dimaksud. Sadar bahwa DPR sebagai lembaga pembentuk undang-undang di dalamnya sarat dengan kepentingan, maka sudah seharusnya lembaga tersebut tidak dapat melepaskan diri dari kegiatan kontrol. ${ }^{20}$

20 Eddy Purnama, Op.Cit, hlm. 248-249. 
Lemahnya akuntabilitas wakil rakyat terpilih tidak terlepas dariketiadaan mekanisme kontrol yang lebih ketat oleh rakyat terhadap wakilnya yang duduk di lembaga perwakilan. Ketiadaan mekanisme kontrol disebabkan tidakterbangunnya ikatan institusional antara anggota DPR dengan pemilih pascapemilu. ${ }^{21}$ Dengan demikian perlu adanya lembaga yang memiliki tugas utamasebagai penjaga moral anggota DPR melalui penegakan kode etik yaitu MahkamahKehormatan DPR.

Tindakan-tindakan yang melanggar hukum khususnya tindak pidana korupsi banyak terjadi di lingkungan DPR. Hal ini tentu sangat memprihatinkan. DPRyang seharusnya sebagai kepanjangan tangan rakyat, justru bertindak menyakiti rakyat. Mereka yang dipilih oleh rakyat, justru melakukan praktik korupsi uang rakyat.

Dalam rangka menegakkan kehormatan dan keluhuran martabat DPR sebagai lembaga perwakilan rakyat, maka di bentuk Mahkamah Kehormatan DPR.

Pasal 119 UU No. 17 Tahun 2014, mengatur bahwa:

\section{(1) Mahkamah}

Kehormatan

Dewan dibentuk oleh DPR dan merupakan alat kelengkapan DPR yang bersifat tetap.

21 Khairul Fahmi, 2010, Prinsip Kedaulatan Rakyat Dalam Penentuan Sistem Pemilihan Umum Anggota Legislatif,Jurnal Konstitusi, Volume 7, Nomor 3, Juni, Sekretariat Jenderal Dan Kepaniteraan Mahkamah Konstitusi, Jakarta, hlm. 152.
(2) Mahkamah Kehormatan Dewan sebagaimana dimaksud pada ayat (1) bertujuan menjaga serta menegakkan kehormatan dan keluhuran martabat DPR sebagai lembaga perwakilan rakyat.

Dengan demikian MKD merupakan salah satu alat kelengkapan yang bersifat tetap. Pembentukan MKD di DPR merupakan respon atas sorotan publik terhadap kinerja sebagian anggota DPR yang buruk, misalnya dalam hal rendahnya tingkat kehadiran dan konflik kepentingan. Secara praktik, anggota DPR dipilih secara langsung oleh rakyat, akan tetapi saluran untuk pencalonan sesuai UUD NRI 1945 adalah melalui partai politik.

Wewenang mengusulkan anggota DPR untuk diberhentikan dapat melalui dua pintu, yakni MKD dan partai politik. Dalam hal anggota DPR diusulkan oleh MKD untuk diberhentikan, Pasal 147 Ayat (2) UU No. 17 Tahun 2014 tentang MPR, DPR, DPD dan DPRD, menentukan bahwa:"Putusan Mahkamah Kehormatan Dewan mengenai pemberhentian tetap anggota sebagaimana dimaksudpada ayat (1) harus mendapatkan persetujuan rapat paripurna".

Dalam Pasal 240 ayat (1) UU No.17 Tahun 2014tersebut di atas, bahwa ketentuan yangmenyebutkan "diusulkan oleh pimpinan partai politik kepada pimpinan DPRdengan tembusan kepada Presiden". Ketentuan 
tersebut menurut Ni'matul Huda dapat dimaknai keputusan recalling terhadap anggota DPR barulah usul dan keputusannya terserah pimpinan DPR danPresiden. ${ }^{22}$

Jika dilihat pelaksanaan tugastugas koordinatif dan protokoler pimpinan DPR maka pimpinan DPR bukanlah 'atasan' para anggotaDPR. Pelaksanaan pergantian antar waktu anggota DPR harus lebih dahulu dimusyawarahkan kepada pimpinan DPR dan peresmiannya dilakukan oleh Presiden, kedua tata cara prosedural tersebut hanyalah formalitas belaka. Menurut Undang-Undang, mengganti anggota DPR adalah wewenang penuh orsospol dalam hal ini partai politik. ${ }^{23}$

Dalam UU No. 2 Tahun 2011 tentang Partai Politik, telah diatur juga tentang pemberhentian anggota partai politik di DPR, Pasal 16 ayat (3) menentukan bahwa: "Dalam hal anggota Partai Politik yang diberhentikan adalah anggota lembaga perwakilan rakyat, pemberhentian dari keanggotaan Partai Politik diikuti dengan pemberhentian dari keanggotaan di lembaga perwakilan rakyat sesuai dengan peraturan perundang-undangan.”

Sebagai organisasi yang diberikan wewenang mengajukan calon pejabat politik, partai politik

22 Ni'matul Huda,2011, Dinamika Katatanegaraan Indonesia Dalam Putusan Mahkamah Konstitusi, FH UII Press, Yogyakarta hlm. 166.

23 Yusril Ihza Mahendra, 1966, Dinamika Tata Negara Indonesia, Gema Insani Press, Jakarta, hlm.151 juga mempunyai wewenang untuk melakukan usulan pergantian dan pemberhentian anggota DPR. Usulan pergantian dan pemberhentian ini yang lazim disebut recall, merupakan kekuasaan politik yang sangat rentan dengan kesewenang-wenangan. Hal ini disebabkan pimpinan partai politik dapat mengusulkan pergantian dan pemberhentian seseorang dari partai politik dan keanggotaannya di DPR hanya berbekal pelanggaran $\mathrm{AD} / \mathrm{ART}$ oleh seorang anggota partai.

Pasca keluarnya Putusan MK No. 22-24/PUU-VI/2008 tentang sistem pemilu proporsional terbuka dengan suara terbanyak, seharusnya terkait hak recall tidak sepenuhnya dimiliki partai politik. Pemilih dalam hal ini rakyat juga mempunyai hak, apakah anggota partai politik di DPR tersebut layak diganti atau diberhentikan. Hal ini penting agar tidak terjadi tindakan sewenang-wenang oleh partai politik. Artinyatidak bisa seorang anggota DPR begitu mudah digantidan diberhentikan karena berbeda pandangan dengan induk organisasinya.

Dalam hal pengaturan pemberhentian anggota DPR yang kewenangannya diberikan oleh partai politik, tentu dasar pertimbangan pemberhentian tersebut tidak boleh didasarkan semata pada urusan politik. Tetapi harus dilihat secara menyeluruh termasuk di dalamnya melindungi hak seseorang. Ketentuan itu juga sekaligus menunjukkan konsistensi dalam menerapkan paham supremasi 
hukum, yaitu bahwa setiap orang sama di depan hukum, sehingga setiap warga negara harus tunduk pada hukum. Namun demikian dalam menegakkan hukum itu harus dilakukandengan cara-cara yang sesuai dengan hukum.

Negara hukum atau The Rule Of Law yang hendak kita perjuangkan atau tegakkan di negeri ini ialah suatu negara hukum dalam artiannya yang materiil, The Rule Of Law, yang bertujuan untuk menyelenggarakan kesejahteraan umum jasmaniah dan rohaniah, berdasarkan prinsip-prinsip hukum yang benar dan adil, sehingga hak-hak dasar warga negara betulbetul dihormati(to respect), dilindungi (to protect), dan dipenuhi (to fulfil). ${ }^{24}$

Penggunaan suatu hak recall partai politik terhadap anggota DPR dalamarti kewenangan semata-mata dengan tujuan untuk menjatuhkan anggota DPR merupakan tindakan pelanggaran hak asasi.Penyalahgunaan hak recall partai politik artinya aktivitas partai politik yang timbul dari penggunaan haknya yang merugikan anggota DPR dengan menimbulkan ketidaknyamanan atau terganggunya anggota DPR tersebut.

Kewenangan yang diberikan kepada partai politik terkait pemberhentian anggota DPR khususnya yang disebabkan oleh tindak pidana korupsi sudah seharusnya diatur. Dengan masih

24 Abdul MukthieFadjar, 2013, Perjuangan Untuk Sebuah Negara Hukum Yang Bermartabat, dalam Hariyono, Dkk, Editor, Membangun Negara Hukum Yang Bermartabat, Setara Press, Malang, hlm. 5. diberikannya hak recall di tangan partai politik, maka hal ini tidak boleh dilakukan secara sewenang-wenang. Sudah seharusnya pemberhentian anggota DPR disebabkan karena halhal yang merugikan rakyat, dan bukan karena kesewenang-wenangan partai politik. Hak recall yang terukur pada hakikatnya tidaklah bertentangan dengan demokrasi. ${ }^{25}$

Lembaga recall tidak dimaksudkan untuk dominasi partai politik yang tanpa batas (tirani partai politik), tetapi harus diletakkan pada kerangka proporsionalitas dan obyektifitas menurut ketentuan perundang-undangan yang berlaku. Lembaga recall bertujuan untuk melakukan pengawasan (control) terhadap anggota partai politik yang menjadi anggota Dewan Perwakilan Rakyat, yang pada gilirannya diharapkan dapat meningkatkan kinerja, akuntabilitas dan integritas anggota Dewan Perwakilan Rakyat itu sendiri.

Sebagai badan pengawas, pengatur dan wakil, parlemen modern adalah pusat perjuangan untuk mewujudkan dan memelihara tata kelola pemerintahan yang baik dan untuk memberantas korupsi. Anggota parlemen adalah inti demokrasi. ${ }^{26}$ Parlemen harus diisi oleh orang-orang berintegritas untuk mendorong tata kelola pemerintahan yang baik dan bebas KKN.

\footnotetext{
25 Ni'matul Huda, Op.Cit, hlm.184.

26 Jeremy Pope, 2003, Strategi Memberantas Korupsi (Elemen Sistem Integritas Nasional), Yayasan Obor, Jakarta, hlm.89-90.
} 
Sebagai organisasi yang diberikan hak istimewa untuk mengajukan calon-calon pemimpin politik, sudah seharusnya partai politik memberikan calon-calon yang bersih. Banyaknya anggota partai politik yang duduk di berbagai lembaga politik khususnya di DPR yang terlibat korupsi, kiranya undang-undang partai politik perlu ditinjau kembali.

Menurut Maria Farida Indrati, peraturan perundang-undangan yang baik harus berdasarkan asas-asas pembentukan peraturan perundangundangan. Hal ini sebagai pedoman atau suatu rambu-rambu dalam pembentukan peraturan perundangundangan yang baik. ${ }^{27}$ Menurut Bagir manan, suatu peraturan perundangundangan yang baik didasari pada 3 (tiga) hal, yakni: dasar yuridis, dasar sosiologis dan dasar filosofis. ${ }^{28}$

Ketiga landasan ini menjadi penting agar peraturan yang dibentuk menjadi efektif, sehingga dapat diterima secara wajar dan luas serta berlaku untuk jangka waktu yang panjang. Di samping itu, peraturan perundang-undangan yang baik adalah peraturan yang mampu memenuhi rasa keadilan dan menjamin kepastian hukum serta memenuhi harapan dan tuntutan masyarakat.

Dari uraian di atas konstruksi terhadap ketentuan pemberhentian

27 Maria Farida Indrati,2007, Ilmu PerundangUndangan (Jenis, Fungsi Dan Materi Muatan), Kanisius, Yogyakartah. 252.

28 Rachmat Trijono, 2014, Dasar-dasar Ilmu Pengetahuan Perundang-Undangan, Papas Sinar Sinanti, Jakarta, hlm. 40. anggota DPR yang penting adalah merevisi ketentuan Pasal 16 ayat (1) UU No. 2 Tahun 2011 yakni dengan merumuskan ketentuan tentang tindak pidana korupsi sebagai salah satu syarat pemberhentian anggota DPR, dengan pertimbangan bahwa sebagai penyelenggara negara, DPR harus bersih dan bebas $\mathrm{KKN}$ serta mempertimbangkan bahwa korupsi bertentangan dengan tujuan bernegara yang terdapat dalam Pancasila sebagai dasar negara dan Pembukaan UUD 1945 dan merumuskan ketentuan mekanisme pengusulan pemberhentian anggota DPR yang terkait tindak pidana korupsi oleh pimpinan partai politik.

\section{KESIMPULAN}

Berdasarkan pembahasan diatas dapat disimpulkan sebagai berikut:

1. Partai politik yang diberikan kewenangan mengajukan calon anggota DPR, diberikan kewenangan juga untuk melakukan pemberhentian anggota partai politik di DPR. Ketentuan tentang syarat pemberhentian anggota partai politik di DPR dalam Pasal 16 ayat (1) saat ini sangat normatif, seperti karena meninggal dunia, pindah partai lain dan melanggar AD/ART. Ketentuan lain sebagai syarat pemberhentian anggota partai politik di DPR seperti karena melakukan korupsi tidak diatur, sementara banyak 
anggota partai politik di DPR terjerat kasus korupsi.

2. Konstruksi pengaturan terhadap ketentuan dalam Pasal 16 UU No. 2 Tahun 2011, memberikan kewenangan kepadapartaipolitik untuk melakukan pemberhentian anggota partai politik di DPR. Merujuk Pasal 22B UUD NRI Tahun 1945 maka syarat-syarat pemberhentian anggota partai politik di DPR yang diatur dalam Pasal 16 ayat (1) dan ayat (3) masih sangat normatif, belum mengatur konstruksi syarat yang lebih khusus, seperti tindak pidana korupsi.

\section{DAFTAR PUSTAKA}

\section{Buku}

Asshiddiqie, Jimly, 2015, Pengantar Ilmu Hukum Tata Negara,

Radja Grafindo Persada, Jakarta., 2008, Pokok-Pokok Hukum Tata Negara Indonesia, Bhuana

Ilmu Populer, Jakarta.

Amal, Ichlasul Amal \& Samsurizal Panggabean, 2012, Reformasi Sistem Multi-Partai Dan Peningkatan Peran DPR Dalam Proses Legislatif, dalam Ichlasul Amal, Dkk, Editor, Teori- Teori Mutakhir Partai Politik, Tiara Wacana, Yogyakarta

Cohen, L. Morris and Kent C. Olson, 1992, Legal Research In a Nutshell, West Publishing Co., United State of America.
Cholisin \& Nasiwan, 2012, DasarDasar Ilmu Politik, Ombak, Yogyakarta.

Diantha, Pasek, 2016, Metode Penelitian Hukum Normatif(Dalam Justifikasi Teori Hukum), Prenada Media Group, Jakarta

Fadjar, Abdul Mukthie, 2013, PerjuanganUntuk Sebuah Negara Hukum Yang Bermartabat, dalam Hariyono, Dkk, Editor, Membangun Negara Hukum Yang Bermartabat, Setara Press, Malang.

Fahmi, Khairul, 2011, Pemilihan Umum \& Kedaulatan Rakyat, Rajagrafindo Persada, Jakarta.

Gaffar, Janedjri, 2013, Demokrasi dan Pemilu Di Indonesia, Konpress, Jakarta

Huda, Ni'matul, 2011, Dinamika Katatanegaraan Indonesia Dalam Putusan Mahkamah Konstitusi, FH UII Press, Yogyakarta.

H. Zainuddin, 2011, Metode Penelitian Hukum, Sinar Grafika, Jakarta

Indrati, Maria Farida, 2007, Ilmu Perundang-Undangan (Jenis, Fungsi Dan Materi Muatan), Kanisius, Yogyakarta.

Ibrahim, Johnny, 2013, Teori \& Metodologi Penelitian Hukum Normatif

(Edisi Revisi), Bayumedia Publising, Malang.

Lutfi, Mustafa, 2010, Hukum Sengketa Pemilukada Di Indonesia, UII Press, Yogyakarta. 
Marzuki, Peter Mahmud 2010, Penelitian Hukum, Kencana Prenada

MediaGroup, Jakarta.

Mage, Ismail Ruslan, 2013, Berpolitik

Dengan Biaya Murah (Solusi, Mencegah Politisi Korupsi), Thafa Media, Yogyakarta.

Mahendra, Yusril Ihza, 1966, Dinamika

Tata Negara Indonesia, Gema Insani Press, Jakarta.

Napitupulu, Paimin, 2007, Мепијu

Pemerintahan Perwakilan,

Alumni, Bandung.

Purnama, Eddy, 2007, Negara

Kedaulatan Rakyat, Analisis

Terhadap Sistem Pemerintahan

Indonesia dan Perbandingannya

Dengan Negara-Negara Lain,

Nusamedia, Bandung.

Pope, Jeremy, 2003, Strategi

Memberantas Korupsi (Elemen

Sistem Integritas Nasional),

Yayasan Obor, Jakarta.

S. Kusnu, Goesnidhie, 2010, Hukum

Konstitusi Dan Politik Negara

Indonesia, Nasa Media, Malang.

Soekanto,Soerjono, dan Sri Mamuji,

2011, Penelitian Hukum

Normatif Suatu Tinjauan

Singkat, Rajagrafindo, Jakarta.

Trijono, Rachmat, 2014, Dasar-dasar

Ilmu Pengetahuan Perundang-

Undangan, Papas Sinar Sinanti, Jakarta.

Yuhana, Abdy, 2013, Sistem Ketatanegaraan Indonesia Pasca Perubahan
UUD 1945, Sistem Perwakilan Di IndonesiaDan Masa Depan MPR RI, Fokus Media, Bandung.

\section{Jurnal}

Fahmi, Khairul, 2010, Prinsip Kedaulatan Rakyat Dalam Penentuan Sistem Pemilihan Umum Anggota Legislatif,Jurnal Konstitusi, Volume 7, Nomor 3, Juni, Sekretariat Jenderal Dan Kepaniteraan Mahkamah Konstitusi, Jakarta.

Wahid, Nur Hidayat, 2007, Eksistensi Lembaga Negara Berdasarkan Undang-

Undang Dasar Republik Indonesia Tahun 1945, Jurnal Legislasi Indonesia, Vol. 4 No. 3September, Direktorat Jendral Peraturan Perundang-undangan Departemen Hukum Dan HAM RI, Jakarta.

Asshiddiqie, Jimly, 2006, Partai Politik Dan Pemilihan Umum Sebagai

Instrumen Demokrasi, Jurnal Konstitusi, Vol. 4, Nomor 3.

\section{Peraturan Perundang-Undangan}

Undang-Undang Dasar Negara Republik Indonesia Tahun 1945.

Undang-Undang Negara Republik Indonesia Nomor 14 Tahun 2014 tentang MPR, DPR, DPD Dan DPRD (Lembaran Negara Republik Indonesia Tahun 2014 Nomor 182). 
Undang-Undang Negara Republik Indonesia Nomor 2 Tahun 2011 tentang Perubahan Atas UndangUndang Nomor 2 Tahun 2008 Tentang Partai Politik(Lembaran Negara Republik Indonesia Tahun 2011 Nomor 2).

Putusan Mahkamah Konstitusi Nomor 22-24/PUU-VI/2008 tentang Pengujian Undang-Undang Nomor 10 Tahun 2008 tentang Pemilihan UmumAnggota Dewan Perwakilan Rakyat, Dewan Perwakilan Daerah, dan DewanPerwakilan Rakyat Daerah. 